\title{
Rejecting and challenging illocutionary acts
}

\author{
Mariya Chankova \\ South-West University
}

This paper examines aspects of strategic interaction and the construction of the social actor in a neo-Austinian framework of illocutionary acts. The basic premise of the neo-Austinian framework is conventionality, according to which illocutionary acts depend on social agreement. An important part of the framework is the felicity condition of entitlement, directly related to the hearer's understanding of the conventions that should hold for an act performance. Two strategies of challenging and/or rejecting illocutionary acts are then identified tentatively dubbed looping and backfiring, related to the hearer's perception of when the entitlement felicity condition is flouted. Both strategies can be overtly or covertly confrontational and demonstrate that in their social quality illocutionary acts serve to construct the social actor and build up interpersonal relations.

Keywords: strategic interaction, illocutionary acts, entitlement, social actor, rejecting, challenging

\section{Introduction}

Both attenuating (mitigating) and boosting the illocutionary force have been given their share of research (Holmes 1984; Caffi 1999; Sbisà 2001; Wee 2004). Arguments have been made that traditional speech act theories (such as Searle's 1969, 1979, 1983; but also Bach and Harnish's 1979) neglect the role of the hearer (Streeck 1992, Clark \& Carlson 1982); the only consideration of the 'bearer of the acoustic blast' is that she must recognize communicative and illocutionary intentions (Searle 1992). As Witek rightfully noted, most of speech act theoretic research adopts a single-act perspective $(2015 \mathrm{a}, 13)$, whereas a conversational perspective would allow for some insight on the impact attempted acts might have had on the hearers (Sbisà 1992). An engaging holistic approach to the so-called Austin-games that attempts to grasp speech act performances in their complexity, with locutionary games, illocutionary games and perlocutionary games, is suggested by Witek in an insightful paper (2015a). In order to paint a more realistic 
picture of how illocutionary acts come to be, I adopt here an interactional perspective - one which considers the occurrence of illocutionary acts in a particular speech situation together with the hearer's response (or sequel) to them (also, Witek 2015b) - and I set out to explore how acts can be challenged or rejected in strategic interaction. I focus on strategic contexts because they reveal the social actors as strategists who display awareness of their need to anticipate their interlocutors' conversational moves in ways that transcend cooperative, open side of interaction and who work towards projecting a particular social image while they pursue a strategic goal.

The question explored here is how illocutionary acts help construct the social actor in interaction, given that the hearer is not a disinterested participant, but one with her own aims, agenda, desires, intentions, feelings, and so on, which affect her interpretation of social reality. Strategic interaction contexts offer a vast array of misfires and misexecutions (recall Austin's doctrine of infelicities, 1962,18), of attempted illocutionary acts which are challenged or rejected by the hearers. It is the challenging and rejecting of illocutionary acts that this discussion will be focusing on. Returning to Austin's original ideas on speech acts, I shall present a neo-Austinian framework for illocutionary acts, supplemented by an entitlement felicity condition which provides the background illocutionary act performances are judged upon by interlocutors. Such an approach is not exactly new, but it does not have a lot of supporters (Sbisà 2002, 2007, 2009; Dörge 2004 and Witek 2015a, $2015 \mathrm{~b}$ are among the few).

I shall first expound the groundwork for the theoretical framework I propose, emphasizing the conventionality of illocutionary acts (Section 2.1.), and I shall explain what challenging and rejecting an illocutionary act would consist of (Section 2.2.). I shall then proceed to a discussion of the entitlement condition upon which challenging and rejecting are based and which puts due prominence to the role of the hearer in illocutionary act performance in Section 2.3. The mechanism of constructing the social actor is unveiled in Section 2.4., followed by a discussion of the strategies for rejecting and challenging illocutionary acts, which are introduced via examples from political interviews in Section 3., before a short conclusions section.

\section{The neo-Austinian framework for illocutionary acts}

The neo-Austinian framework of illocutionary acts that is advocated here focuses on a general phenomenology of social interaction in terms of the social moves undertaken by social actors who work on their environment in ways that affect both the environment itself and the interpersonal relations. The term 'social actor' 
is built on Goffman's work (1959) and is taken here to refer to a special representation of self that encompasses a set of conveyed intentions, attitudes, commitments to values (more on the term in Section 2.4.). The social actor projects an image to the public by both her intentional actions (e.g. her illocutionary acts) and conveyed attitudes that escape her intentions (resulting from the interpretation the hearer makes of some of the verbal and non-verbal input of the speaker). The neoAustinian framework of illocutionary acts is constructed around the following concepts: Austin's notion of conventional illocutionary acts which have conventional illocutionary effects and a reconsidered (set of) felicity condition(s). Those concepts shall be detailed below.

\subsection{Illocutionary acts}

In my understanding, illocutionary acts are those acts that operate non-natural ${ }^{1}$ changes on our social environment, more often than not accomplished by the utterance of a string of words. This description is derived from Austin's writings and it is based on the following intuitive ideas about illocutionary acts: (i) they are social phenomena that have a certain external manifestation (not necessarily a linguistic one); (ii) the manifestation itself does not need to be conventionally associated with that particular act, as it is subject to interpretation in a set of particular circumstances; (iii) the social act has a target ${ }^{2}$ and (iv) it takes effect in a certain way. These four ideas are modulations on Austin's original discussion of illocutionary acts for the following reasons: (i) it needs to accommodate for non-verbal cases (something that Austin admitted to, 1962,19); (ii) it stems from Austin's (fruitless) efforts to distinguish a special (grammatical) class of sentences that serve to perform the illocutionary acts they explicitly name; (iii) it is implicit in both the idea that speakers should "secure uptake" (Austin 1962,138) and (iv) the tentative taxonomy of illocutionary acts suggested by Austin, in which the acts exploit social dimensions or build up interpersonal relations of different kinds. The social character of the acts is rooted in (iii) and (iv) - their being directed at a recipient, and their effect that actively changes the social environment. These are acts, in short, that are abstract, non-material entities (also Dörge 2004) that serve to redesign interpersonal relations.

1. I borrow Grice's term (1957) which seems to aptly capture the idea that illocutionary acts produce effects which are not natural or logical consequences of actions, but are a matter of social contract, as Austin conceived of them.

2. The archery metaphor is supposed to capture the idea that an illocutionary act performance is aimed at a person (not necessarily the hearer) to be changed or influenced by the act. 
The way illocutionary acts can achieve this active rearrangement of the social environment is rooted in their conventionality. Illocutionary acts are conventional in the sense of socially conditioned, socially accepted practice, sanctioned by a particular group. Sbisà $(2002,421$, footnote 1$)$ explains the term of social action as one that "needs a social environment". The neo-Austinian framework thus encompasses an action dimension (which is the illocutionary effect of the act), a re-evaluated role of the hearer (to whom the act is directed), and a reconsidered notion of context (which fixes illocutionary act performances to specific participants in a specific situation).

Austin originally proposed a set of conditions which must be satisfied in the performance of an illocutionary act if that act is to be successful (I quote the paragraph at length):

(A. 1) There must exist an accepted conventional procedure having a certain conventional effect, that procedure to include the uttering of certain words by certain persons in certain circumstances, and further,

(A. 2) the particular persons and circumstances in a given case must be appropriate for the invocation of the particular procedure invoked.

(B. 1) The procedure must be executed by all participants both correctly and

(B. 2) completely.

(Г. 1) Where, as often, the procedure is designed for use by persons having certain thoughts or feelings, or for the inauguration of certain consequential conduct on the part of any participant, then a person participating in and so invoking the procedure must in fact have those thoughts or feelings, and the participants must intend so to conduct themselves, and further

(Г. 2) must actually so conduct themselves subsequently. (Austin 1962,14-15)

Two remarks in this respect: first, Austin $(1962,16)$ stressed upon the fundamental difference in the nature of $\mathrm{A}$ and $\mathrm{B}$ rules on the one hand and $\Gamma$ rules on the other, namely that flouting $\Gamma$ rules cannot make the act null and void. The $\mathrm{A}$ and $\mathrm{B}$ rules function as basis for constituting any given behavior as being a particular illocutionary act. Those rules are norm or rule templates (as Sbisà, 2018, describes them) in that they identify the procedure and additional requirements for appropriateness in illocutionary act performance. Second, adherence to thoughts, beliefs and sincerity in general cannot be ascertained and speakers and hearers rely on the communicated beliefs and conveyed attitudes, often taking for granted that associated psychological states for illocutionary act performances obtain. Thus, in the elaboration of a definition of illocutionary acts under the neo-Austinian framework, $I$ have eliminated $\Gamma$ rules from consideration. I propose the following description of the notion of illocutionary acts, 
which includes necessary and sufficient conditions, grafted on A and B rules of Austin's doctrine of infelicities:

An act is an illocutionary act iff

1. It is a conventional act in the sense that it requires conformity to an accepted conventional procedure and has a conventional effect, and

2. It requires the securing of uptake in order to take effect. ${ }^{3}$

There are thus two senses in which illocutionary acts are conventional: they have a conventional procedure and they have a conventional effect. The first involves the invocation of a social ritual in the sense of what is said to whom and in what circumstances, which is accepted to be a particular kind of act. The word 'accepted' is supposed to be used as a technical term here - at least, Austin construes it as such $(1962,27-29)$ - meaning that the members of the group have conjointly defined a socially significant act with socially significant effects; in other words, it is a product of social agreement and it should not be confused with accepting the performance (as being correct, valid, and the like). According to Sbisà, one realization of the conventional procedure can be seen in the idea that there must be an agreement among the social participants on the kind of deontic properties illocutionary acts will be implementing upon their successful performance $(2002,2007)$. To reiterate, the conventionality of illocutionary acts lies in their being social contracts, agreed upon practices that need a social environment to come about. The words the speakers will utter need to invoke that particular procedure in a way that the hearers understand which illocutionary act the speaker attempts to perform.

It is a rather trivial observation that the social groups' needs of particular social contracts change with time; the requirements/ felicity conditions of illocutionary acts may change as well. ${ }^{4}$ The core of the notion of illocutionary acts lies in the social significance of a practice which redesigns interpersonal relations; as such, the task of defining illocutionary acts is not subsumed by the question of describing a ritual or ceremony, but in pinpointing a practice (a doing) which has a special ontological character. Illocutionary acts are thus phenomena that occur in and/or are enabled by communicative processes, but they are not exhausted by communicative purposes.

3. These elements in the illocutionary act description are found in Dörge (2004), Sbisà (2007), and Witek (2015b).

4. Consider the act of declaring independence: different speakers and hearers have quite different ideas on what the procedure of the act should consist of. A social practice which has outgrown its importance is dueling: as standards of honorable behavior and problem-solving strategies in modern society changed, the practice of dueling passed into history. 
Austin's procedure constitutes the entire sequence of actions, intentions, consequences, ritual (if any), circumstances, the role and status of the speaker and hearer involved, the effects, the conditions - in one word, everything. Austin says:

It is inherent in the nature of any procedure that the limits of its applicability, and therewith, of course, the 'precise' definition of the procedure, will remain vague.

$(1962,31)$

Since Austin does not provide directions as to the scope of illocutionary procedures, the burden on the hearer's uptake becomes more important, the hearer having to evaluate every performance for satisfying the criteria for being an invocation of that procedure. Two remarks: first, as Austin points out, in order to avoid a certain arbitrariness, we tend to be bound by the precedents we set (there are many examples to this in law, but also in everyday communicative situations). Second, there is a very real possibility that every speaker and every hearer would have their own personal criteria of assessing the procedure of an act. Common practice seems to corroborate this: institutional illocutions are generally defined in an official way in constitutive texts; within the boundaries of our society we are aware of the procedure for marrying somebody, for selling a property, for casting votes in elections, for testifying before a court of law etc. Even among institutional illocutions there is room for singular instances which need to be decided upon. In ordinary life, "allowances are made" (Austin 1962,32): hearers may accept that an act has been performed even if there is variation in the procedure. It has also been suggested that interlocutors tend to take for granted that illocutionary acts are felicitous, that all the conditions for the performance of the act are met (Sbisà 2002).

Importantly, Austin allowed for the subjective evaluations of illocutionary act performances by noting that hearers could reject the invocation of a procedure coming from one particular speaker and accept it from another one $(1962,27)$, and further, that it should be possible for hearers to reject any procedure in principle $(1962,29)$. It stands to reason to assume that illocutionary act procedures are based on repetitive, recognizable sequences/ rituals (as Sbisà, 2018, does), but how the hearer construes the extent to which these sequences/ rituals must be executed in order to count as a performance of that illocutionary act can (and should) fluctuate (Austin 1962,31).

The second part of the description of illocutionary act posits a requirement that the speaker must secure uptake, that is, do everything possible to bring about the hearer's understanding of the procedure. It is important to note here that the invoked procedure can be validated or not by the hearer, making the hearer at least partially responsible for the performance of the act. 
Another conventional aspect of illocutionary acts is the illocutionary effect. Being non-material, illocutionary acts produce conventionally attached non-natural effects. Hardly any scholar (after Searle's modified version of it $)^{5}$ has paid a lot of attention to the conventional effect of illocutionary acts. One of the few who have done that is Sbisà $(1984,2001)$. Her suggestion, which deserves a lot of merit, is that conventional effects are to be understood in terms of 'deontic modality' "namely, as assignments to or cancellations from each one of the participants of modal predicates related to the necessity or possibility of actions with respect to norms" $(2001,1797)$. The reason for choosing the deontic lexicon is explained by Sbisà by the conventional character of the assignment or removal of obligations a process depending on social factors, including foremost the relevant intersubjective agreement. Illocutionary effect is conventional in that it is invariably attached to the successful performance of the illocutionary act.

\subsection{Challenging and rejecting illocutionary acts}

In accordance with the definition above, the illocutionary act will be successful if the speaker felicitously invokes the procedure and manages to secure the hearer's uptake. Conversely, an illocutionary act will be rejected if the hearer does not hold the speaker to be in a position to perform the attempted act and seeks to prevent the implementation of the illocutionary effect of that act. Austin's misinvocations fall into this category, where the very procedure is deemed inexistent or inappropriate. The hearer challenges the act if she has any reason to believe that the speaker might not be in a position to perform the attempted act or if the hearer finds anything wrong with the execution of the procedure. This contribution focuses on cases in which it would be difficult to ascertain whether the invoked procedures have any flaws, but which lend support to Austin's claim that hearers should be able to reject illocutionary performances in principle (see above). Rejecting the attempted act translates as the hearer's unwillingness to be held committed to the implementation of its illocutionary effect; on the other hand, challenging the act may lead to further negotiating commitments and effects. Both rejecting and challenging may effectively result in invalidating the attempted act; both may as well fail to invalidate or indeed call into question the attempted act. This is a point I will return to later on.

In interaction, rejecting or challenging the illocutionary act consists in signaling that the act did not take effect, or in other words, signaling the hearer's

5. Searle's take on the illocutionary effect (1969) ties it with the meaning of the items uttered by the speaker, consisting thus "simply in the hearer understanding the utterance of the speaker" $(1969,47)$. 
unwillingness to have the illocutionary effect implemented/ validated. Usually, this is achieved by a communicative intervention by the hearer, but it may also be nonverbal. However, the hearer's rejecting or challenging an act does not depend on the performance strategies the speaker chose. Since rejecting (challenging etc.) illocutionary acts takes its root from Austin's doctrine of infelicities, rejecting and challenging will ideally concern cases where the conventional procedure invoked is executed incompletely or incorrectly. In strategic interaction this decision will also be subjective and idiosyncratic: speakers tend to have an idea of the response pattern of their interlocutors, based on their previous experience; thus, they can anticipate to a certain extent how the interaction is going to unfold; or else, in order to achieve their personal strategic goals, they may use the response pattern of their interlocutors to their advantage (if they are familiar with it), they may rely on social features or personal qualities that transcend the interaction, or they may exploit any personal weakness of the interlocutor. It is important to underline here that from a communicative point of view, the words of a rejected illocutionary act may still make communicative sense, even though the attempted act may not have taken hold. It is also important to note that the interlocutors will more often than not be fully aware of which act exactly they are rejecting or challenging. Thus, rejecting and challenging illocutionary acts does not concern matters of deciding which illocutionary act the speaker is attempting to perform, but rather how interlocutors evaluate their respective positions (for more details on the entitlement felicity condition, see Section 2.3. below). In tune with the basic premises of strategic interaction, the participants will no longer take for granted that the act's performance meets the conditions required; an additional degree of formality may dominate the exchange (Akinnaso uses the term "solemnity", 1985), and the participant will judge the exchange for conformity with (her own understanding of) the entitlement (felicity) condition.

\subsection{The entitlement felicity condition}

The entitlement felicity condition is fundamentally different in nature from the conditions originally described by Austin or Searle. This difference is rooted in the second remark on conventional procedure above: speakers and hearers will have their own idiosyncratic understanding about the precise parameters of a particular illocutionary act procedure. This should not be read to say that illocutionary acts are performed in an arbitrary fashion; it merely reflects a trivial observation about human nature, namely that people, as real live participants with their own feelings, desires, intentions and goals, evaluate in a subjective way how performances conform to their idea of entitlement/ power/ authority and 
the like. In the absence of a clear-cut objective description of what the conventional procedure of an illocutionary act should contain and how it ought to be executed, the act performances are judged based on a (set of) hearer-based felicity condition $(s)^{6}$ of entitlement. In its core there lies an evaluation of the position of the speaker in regard to the act in question; for instance, whether the speaker has the proper authority to issue verdictives, or has the right to perform exercitives, or has the intention to be held committed when attempting a commissive act. $^{7}$ It is important to note here that in general those evaluations concern qualities (or properties, or rights, authority etc.) that are not permanently attached to any speaker in a particular context - they can vary greatly from contexts to contexts and from hearers to hearers.

The entitlement condition is thus meant to capture some parameters of the elusive notion of conventional procedure, which is at the heart of the illocutionary act performance. As such, the entitlement condition partially includes A rules as outlined by Austin ${ }^{8}$ and is thus part of the procedure. It involves a special kind of judgment that the interaction participants make every time somebody attempts to perform an illocutionary act. The entitlement condition embodies the rather general idea of whether the person attempting the act is in a position of doing so. The correspondence sought here is related to matters of social power (also, Sbisà 2001), but also concerns a subjective evaluation of the appropriateness of that person's attempt at performing the illocutionary act in question. The entitlement felicity condition allows us to match up the speaker's belief about her entitlement to perform a particular illocutionary act and the hearer's perception of the speaker's entitlement to do so. It is connected with the way the speaker positions herself in interaction vis-à-vis her interlocutor and the way her interlocutor construes her. The entitlement condition does not follow Searle's logic in felicity conditions, which state the necessary and sufficient conditions for the successful performance of illocutionary acts. If Searle's conditions obtain, then the act is necessarily successful, thus virtually excluding the hearer from the process.

The entitlement condition seeks to capture the social dimension in order to set some restrictions on the illocutionary act procedure. Can I assert (and not guess) that there are fifty people in the next room if I have no means of actually knowing this (Austin's example)? Can I assert that The Name of the Rose is Eco's best novel when people can have different takes on what makes a novel good or bad? Taking

6. The plural is supposed to accommodate the possibility of expanding the list of felicity conditions that come into play in illocutionary act performances.

7. I will, for obvious reasons, use Austin's classification of illocutionary acts. As the scope of the present paper does not permit it, questions of its adequacy will not be addressed.

8. Of course, Austin did not explicitly talk about felicity conditions. 
another of Austin's examples, can I assert that Lord Raglan won the battle of Alma when Lord Raglan's orders were never transmitted to soldiers and he himself was not present at the battlefield?' Speakers, as well as hearers, will evaluate their entitlement to assert with regard to a specific purpose and a specific context which is thereby constructed. Speakers who assert using exaggerations or approximations evaluate the overall effect of the assertion on their own image as 'asserters' against the purposes their assertion is supposed to fulfill in the specific situation: sometimes the emotion or the sentiment takes precedence over the strictness or truthfulness of one's contribution; at other times, sacrificing strictness or truthfulness for emotion can have a heavy cost on the speaker's image, usually stemming from a misjudgment (or miscalculation) of the context. ${ }^{10}$ Entitlement also concerns the social position of the speaker and how it is construed by the hearer. The perspective adopted here is the hearer's: this particular kind of judgment provides a restriction on the types of performances the hearer will accept as conforming to her understanding of the illocutionary act procedure.

Rejecting an illocutionary act will mean that in the particular circumstances the hearer considers that the speaker is not entitled to perform the attempted illocutionary act. If the hearer wishes to call into question the speaker's entitlement to be invoking a particular illocutionary act procedure, she is challenging the act. ${ }^{11}$ It is, however, to be noted that the hearer's role is not that of illocutionary act police, ruling over issues of accuracy or appropriateness of a procedure invocation; it is, first, a matter of (subjective) perception of the performance's conformity/ appropriateness/ accuracy and second, it is an issue of social image construction.

\subsection{Constructing the social actor}

The aspect of illocutionary act performance which is under investigation here is the social action dimension; more precisely the mechanism of constructing the social actor. Participants will use illocutionary acts to project commitments,

9. Note that it is not a truth/falsity evaluation. As hearers, we may accept that the commander is responsible for his troops, thereby validating the approximation and accepting the entitlement of the speaker to claim this.

10. In the era of post-truth and alternative facts, there are many public examples of the cost of this kind of judgment.

11. It has been suggested to me that challenging would be a sign of the hearer's willingness to salvage the illocutionary act of the speaker, thus allowing him to remedy or otherwise respond to the challenge (anonymous referee). As mentioned above, the challenge is in itself an invitation to negotiation. Although it should be said that in the particular context of strategic interaction the hearer may not be committed to salvaging the act; the mere challenge may be strategically self-sufficient, serving to assert or project a particular image of the challenger. 
undertake responsibilities, display qualities and assert stances in order to advance a particular public image of themselves which will serve a specific (cooperative or strategic) purpose.

This dimension of illocutionary act performance goes beyond conditions of felicity, conventional procedures and effects. It concerns features (character traits, emotive perceptions, displayed beliefs, intentions and what not) which help speakers and hearers form an idea about the social position of their interlocutors and their ethical and moral standing, which will in turn enable them to make the entitlement judgment regarding an attempted illocutionary act performance. It is an enactment of Austin's remark that speakers must be able to reject any act, regardless of compliance with procedures and felicity conditions $(1962,29)$. The entitlement condition is thus exploited in pursuit of (strategic) goals. Until now, this dimension has not been formally taken into consideration by speech-act-theory researchers, although some reverberations may be seen in the sincerity discussion, especially in the question about how the hearer perceives the speaker's sincerity (whether the speaker really has all the necessary thoughts, intentions and beliefs). It is generally assumed that interlocutors take these attributes for granted; however, it is important to realize that the attitudes/ beliefs/ intentions etc. projected by the speaker in the performance of the illocutionary act help construct the social actor. This by-product of illocutionary act performances serves as a catalyst for future illocutionary act performances and can greatly impact the way hearers take up on them. Even if the response (the reaction) of the hearer does not appear immediately, the effect of the constructed actor may be cumulative and play a role in subsequent encounters.

The main difficulties in applying the illocutionary act doctrine to communicative settings lie precisely in the complexity of the process of constructing the social actor. Real life exchanges involve speakers and hearers with their own interests, attention spans, aims, desires, intentions, emotions, all of which shape and color their participation in interaction. For the hearer, these can influence the uptake on attempted illocutionary acts by the speaker; indeed, allowances can be made or not on particular performances for a range of reasons. I speculate that rejecting and challenging illocutionary acts might be rare in cooperative exchanges, where interlocutors work towards a common goal. In strategic interaction, personal agendas may influence the way the interlocutors take up on the illocutionary acts, leading them to challenge or reject them. 


\section{Rejecting and challenging illocutionary acts in strategic interaction - some illustrations}

Strategic interaction is a term which relates to game theory: it is an exchange in which the participants evaluate their own moves while making predictions about the moves of their interlocutors so that they can fulfill their personal goal (e.g. Camerer 2003). Habermas' idea of strategic action involves "exerting influence on the decisions of one party on the basis of a calculation of success" $(2000,120)$, which brings in the dimension of manipulation, interesting aspects of which were unraveled in Hansson (2015). In cases of illocutionary act performances, the goal of the participant will be to thwart the interlocutor's efforts to implement an illocutionary effect, usually by initiating a move of their own. Thus, the context of strategic interaction does involve a step back from the communicative action seeking agreement and understanding depicted by Habermas; however, I will not adopt the way Habermas presents strategic action, qualified by Johnson as "derivative" and "unsavory" (1991,189). For the purposes of the present analysis, strategic interaction will mark those contexts that involve participants who privilege their own specific goals (a purpose that more often than not lies beyond interactional purposes) and who (attempt to) anticipate the actions of their interlocutors. Thus, strategic interaction will refer to both an exchange and a whole interactive event: contexts which are not strategic may involve exchanges in which the participants pursue strategic goals. ${ }^{12}$ In the social setting, the interlocutors will struggle to build up their social images while their conceptions of entitlement to perform particular illocutionary acts will clash. In cases of overt confrontation, power relations are at stake as the examples analyzed in this section will demonstrate (the examples come from political discourse or interviews featuring politicians).

The first strategy of rejecting illocutionary acts is tentatively called "looping"; it may be a strategy of overt or covert confrontation. Consider:

(1) James: When did you start smoking?

(2) Donna: I smoke every once in a while. Helps relieve tension.

(3) James: When did you get so tense?

(4) Donna: When I started smoking.

(Twin Peaks series)

12. I owe this point to an anonymous referee. 
Both of James' questions ${ }^{13}$ do not receive the most appropriate (informative, felicitous etc.) answers. The two question-answer pairs are different: it may be that Donna took (1) as a reproach, as her answer provides information about the frequency of her smoking and its beneficial effect of relieving tension, mitigating in a way the seriousness of the deed. Both of James' questions follow a similar pattern, indicating that they might be interpreted as conveying James' surprise of Donna's smoking; this interpretation is strengthened by the fact that at the time this conversation takes place, they had not seen each other for merely a day. It is clear that Donna does not want to answer the question. In terms of image work, she may regard it as invading her personal space by questioning and/or judging her personal choices. As she provides an uninformative answer which closes the information circle back to the initial question, Donna challenges and effectively rejects the act attempted by (3).

When it comes to questions (requests for information), entitlement is difficult to outline. Where do we trace the limit to people's entitlement to ask for personal information? It may be argued that given the short time lapse during which Donna started smoking, James is surprised by it; the two questions taken together reiterate the same request for information, so one might conclude that James is rather venting his emotions than looking for an answer. Since Donna did not smoke before James was taken into custody and is smoking now, it would be reasonable for James to assume that she started smoking some time in between his arrest and her coming in to visit. Thus, James' act could be a behabitive rather than an expositive; this relates more to James' providing a judgment/ attitude towards Donna's behavior. In terms of constructing her social image, Donna manages to assert her right to make her own decisions about different aspects of her life, which she evidently considers to be threatened by James' reproaches.

It is worth pointing out that another difficulty in assessing questions lies in deciding what would constitute a breach of the procedure. Usual practice calls for answers, appealing more to the hearer's cooperation, as questions are not typically described as acts which lay an obligation to answer; it appears that questions are image-constructing acts in the sense that choosing not to answer questions can be detrimental to one's image. There might not be an unambiguous way to reject a question purely on the basis of incorrect (or incomplete) performance. In cases of social blunders (for example, asking after the health of somebody recently deceased) the qualification would rather be along the lines of appropriateness/ inappropriateness; it would be difficult to articulate an actual

13. I will not discuss here the issue of whether or not questions are illocutionary acts. Suffices to note that accepted taxonomies (Austin's, Searle's and even Bach and Harnish's) all include questions. 
procedural problem with the performance. On the other hand, questions can be seen as invading the personal space of the hearer, so it may be argued that hearers would be more attuned to nuances of appropriateness and/or impertinence, which can be construed as entitlement of the speaker to ask a question in a particular situation. For political settings or interviews, questions are a powerful tool to have one's image constructed in a beneficial way for the speaker, but it can be as powerful a tool to take a toll on the speaker's image.

In the exchanges quoted below, looping usually takes the form of trying to transfer responsibility for the (perceived inappropriate) question back to the speaker thus rendering the exchange unproductive (neither information nor specific goals are achieved by the speaker), while there may be little room for the assumption that the hearer has found a problem with the procedure of the illocutionary act she is challenging or rejecting. The speaker will typically claim that it is the entitlement condition which is violated, although, as mentioned above, it might be difficult to claim an exact procedural failure for questions.

The next example features parts of an interview of the deputy chairwoman (DC in the exchange below) of the Central Election Committee (CEC) after footage was released by media showing Committee's employees complain about being held the entire night locked up, while they submitted ballots and protocols:

(5) ВН: ... “Тоест какво ми казвате с това? Че ЦИК не отговаря за (хаоса в) зала "Армеец".

Interviewer: (...) so you're saying that the Central Election Committee is not responsible for (the chaos at) the Armeets Hall (where the employees were heldM. C.)?

(6) Ма разбира се, че това ви казвам!... Видяхте организацията в ЦИК перфектна! Никого не държа заключен. ...Защо не проучите кой държи ключа на тая зала защото не съм аз, нито ЦИК!

DC: Of course that's what I am saying. ... You saw the organization in the CEC, it was perfect! I am not holding anybody locked up.... Why don't you look into who has the key to the Hall, because that's not me, nor the CEC!

(7) BН: (...) Но иначе казвате - бихте искали да ги удушите.

Interviewer: (...) But you said you wanted to strangle them (the ones responsible - M. C.). 
(8) Ама аз не искам да душа никого, казвам ви, че ако майка ми и синът ми... Защо не питате къде е този ключ и кой го държи?!... Вие ми кажете кой държи ключа на общинска собственост. Вие, от вашия дом аз ли държа вашия ключ?

DC: I do not want to strangle anybody. I said if, hypothetically, my mother and son had been held... Why are you not investigating who has the key to the Hall? ... You tell me who has keys to municipality property. You (-) do I have the keys to your home?

(9) ВН: А кой държи според вас ключа за...?

Interviewer: Who do you think holds the key to this ...

(10) Ами вие ще го изясните, като толкова питате. Вие го изяснете.

DC: You will find this out if you insist on asking about it. You find it out (... $)^{14}$

In this exchange (5-10), the interviewer holds the DC accountable for the events that had transpired at ballot turnover, in a standard question session, targeting procedural failings exposed by the footage. The DC, in a desperate attempt to deflect blame, uses the looping strategy to guide the questions into a particular direction and then tries to shift the responsibility back towards the interviewer (10). The responsibility for procedural failings (that the CEC did not have a good plan for processing election officials who came in to turn over ballots and protocols) is transformed into material responsibility, which is far from the original preoccupation of the interviewer, but suits the purposes of the deputy chairwoman. The DC is overtly confrontational and even though she appears to have anticipated the kind of question she would be asked, her response to it is not the most effective. She manages to apply the strategy successfully by the mere repetition of her talking points (she does not hold the key to the Hall and investigating who does is the media's responsibility). Argumentation is replaced by attempts to call the interviewer as witness to the 'perfect' preparations of the CEC, as if willing them to come true. It should also be noted that the chairwoman does not explicitly talk about responsibility, so as not to appear as if she is presenting excuses. The strategy may appear to be reduced to insisting that the interviewer has been asking the "wrong" question, but it is actually an attempt to move beyond any attribution of responsibility to the Central Election Committee and avoiding any discussion

14. The excerpts are taken from various TV programs and feature Bulgarian politicians, officials and public figures; for some of them transcripts by the media themselves are reproduced here; others were transcribed by the author. The transcriptions mark rising (?) and falling (.) intonation contours, omissions (...), pauses (-), unintelligible (portions of) words (x-) and overlaps $\left(^{*}\right)$. My translation from Bulgarian reflects the functionality of the discourse, as the focus of the investigation is the illocutionary act that is being attempted. 
of the footage which has sparked the discussion in the first place. This strategy is quite common for political officials who tend to attack and/or lay blame on the media for asking the wrong questions. In terms of social image work, the deputy chairwoman tries to project a perfect official who is upset by events she bears no responsibility for and is the innocent victim of the persecutions of irresponsible media. The actual projected image is of a hysterical and barely coherent official trying to wiggle her way out of responsibility.

An example of a covert confrontation can be seen in the following exchange (11-14), involving the former director of the National Historical Museum in Sofia, Professor Bozhidar Dimitrov ${ }^{15}$ who speaks of an archeological dig:

(11) B-щ: Това ще бъде ли част от забележителностите там?

Is this (the "holy water" well discovered near the basilica in Pliska - M. C.) going to be part of the curiosities there?

(12) БД: Ма аз не бих. Аз бих акцентирал върху другите, сериозните неща... А сериозните ви ги казах (...) Строена със камък в още 8 век а първата сграда каменна в Англия Лондонският тауер е строена $1067^{*}$

But I wouldn't... I would put emphasis on other aspects the serious things...I told you the serious things (...) It was built with stone in the 8th century whereas the first stone building in England the Tower of London was built in $1067^{*}$

(13) В-щ: * кога ще я видим в цяло(х-) *

when are we going to see it in ent $(x-)$

(14) БД: като за целта Вилхелм завоевателя е докарал камък от Франция (...) for which Wilhelm the Conqueror had stone shipped over from France (...)

In this exchange, the speaker of (12) tries to reject the question by the interviewer who may have aimed to elicit some commentary on the 'holy water' incident from the professor and the strategy seems successful for a while, as the interviewer attempts to place a question about the completed building. It is difficult to assess whether or not the speaker of (12) had anticipated the question about the holy water; he may or may not have; either way, the question angers him as he sees in it an attempt to ridicule the serious matter of archaeological excavations conducted

15. The speaker is late professor of history and former curator of the Historical Museum in Sofia. He was involved in archaeological excavations near Sozopol when a burial site was found with a skeleton bearing traces of a special post-mortem ritual; the professor called the finding "a vampire". During the reconstruction of another historical site, the ancient capital Pliska, a water source was found; the professor sprinkled some water on the PM's head, calling the water "holy" and "magical". Finally, he referred to a conversation he allegedly had with the late self-appointed prophet Vanga as reason for some of his actions today. All three social gaffes were largely taken up by Bulgarian media to add to the reputation of eccentricity that surrounded the professor. 
in the old capital. The impact of the series of events mentioned above on the professor's public image prevents him from calling the interviewer to seriousness. It should be noted that in the long run, the strategy is not successful, as the interviewer brings up the matter once more, eliciting a sharp reaction on the part of the interviewee, leaving the impression that the interviewer was not really interested in the archeological dig, but was in pursuit of cheap sensation. Regardless of the degree of seriousness with which the professor had made his earlier comments about the Sozopol vampire or the holy water, his social image has been affected by them in a way that seems detrimental to his efforts to assert himself in the power struggle that the interview represents. The professor appears to have fallen victim to his own efforts of (over) popularizing historical and archaeological finds.

Consider another variation of the looping strategy from an open conference of the PM with Bulgarian expats in London:

(15) Гражданин: (...) искам да ви попитам по повод статията във Шпигел дали имахте шанс да прочетете, за всичко което се случва последните години свързано със г-н Пеевски, за когото ние не говорим ъъъъ искам да ви попитам, когато четете неговите медии употребявате неговите бизнеси ваши или как да ги нарека общи на всички... “Шпигел” интересно означава огледало на немски. искам да ви попитам започнахте ли да виждате в огледалото когато се погледнете Пеевски? благодаря ви.

Citizen: (...) I would like to ask you about the article in Spiegel if you had time to read it about what has been happening over the last several years with Mr. Peevski who we do not talk about. ummmm I would like to ask you when you read his media use his businesses your or how should I call them everybody's businesses... Spiegel means mirror in German. I wanted to ask you when you look in the mirror do you see Peevski? thank you.

(16) Министър-председател: първо това категорично мога да кажа че не е вярно категорично и със цялата си отговорност за това което казвам и ще ви дам един много конкретен пример - само във последната една година от борбата със контрабандата и корупцията във бюджета сме вкарали 2 млрд 845 млн повече от 2014 година (...)

Prime Minister: first I can say that this is absolutely not true, absolutely and with all my responsibility - I will give you a simple example - over the last year in the fight against smuggling and corruption we upped the budget by 2.845 billion compared to 2014 (...)

The strategy can take the form of feinting acceptance of the illocutionary act (a question on the alleged association between a large media mogul and the PM), but providing a completely irrelevant answer. The demonstrated inability of the PM to reject categorically the allegation contained in the question is highlighted by 
his choice of strategy, which consists in emphasizing the achievements of the government. Audience members punctuate the convoluted explanations with shouts "This was not the question", signaling that the strategy failed. The PM may not have anticipated the question or its direct formulation, this probably due to the fact that direct government official - citizen conferences are not a common occurrence for Bulgarian politicians. The projected social image of the speaker of (16) is that of an official who, in omitting to address the question, indirectly validates the conjectures of the interlocutor.

An example of overt confrontation that shifts back responsibility can be achieved when the speaker considers himself to be in a superior position in the power relations, as demonstrated by the following Example (17-18):

(17) Журналистка: Да ви питам имате ли прогноза колко ще падне цената на горивото с ъъ... във...

Journalist: I want to ask you how much will fuel prices decrease with umm in umm...

(18) Б. Б.: Питайте ме нещо сериозно! Дошъл съм в Смолян откриваме спортни площадки игрища зали. Хората са ги мечтали да ги има - имат ги и продължаваме да работим, и така нататъка.

Prime Minister: Ask me something important! I have come to Smolyan we have been inaugurating sporting facilities halls. The people here had been dreaming about having them - now they do and we keep on working and so on.

The PM takes advantage of the fact that the journalist hesitates and apparently cannot finish her question in order to interrupt her altogether and thus undermine the importance of the question she attempted to ask. Even though she did not quite finish it, recent events allow the public to understand the core of her question (whether decreased oil prices will have an impact on fuel prices). For a variety of reasons the PM considers the question to be out of order, possibly laden with troublesome implications about lack of transparency on the mechanism of forming fuel prices. The PM's response does not take into account the discrepancy in comparing the relative importance ("seriousness") of the inauguration of sporting facilities in a small Bulgarian town on the one hand and fuel prices on the other. The final words of the PM's utterance ("and so on") betray the repetitiveness of the strategy and the blasé way in which it is delivered: these are the party talking points; the partisans will agree with them; opponents are against anyway. The journalist does not renew her question, which clearly indicates that the looping strategy was successful. Both this case and the previous one suggest a pattern in the PM's way of handling unwanted questions. Contrary to the way the PM chose to act in (16), confronted with a journalist from a small 
news agency asking questions outside of the allotted press-conference time, the PM does not shy away from interrupting her.

The second strategy I call "backfiring": the hearer responds to an illocutionary act which was judged to have flouted the entitlement felicity condition by performing a similar illocutionary act that either showcases scandalous or inappropriate language content, or is inappropriate from the illocutionary perspective. This strategy is overtly confrontational and directly challenges the interlocutor. To illustrate the strategy, consider examples (19-20), where Monica confronts her friend Chandler who drank too many jell-O shots:

(19) Monica: Stick out your tongue!

(20) Chandler: Take off your shirt!

(Friends, series)

Chandler may either consider Monica's concern inappropriate or resent the insinuation that he drank too much, which leads him to counter Monica's order by an order to perform an action completely inappropriate for a friend to request. $\mathrm{He}$ thus demonstrates the futility/ inappropriateness of Monica's order by giving an order himself which he is fully aware cannot be complied with, thereby rejecting Monica's order.

A very common variation of this strategy in real life exchanges consists in answering questions by asking another question. Being an overtly confrontational strategy, it may be followed by further negotiations on the relations of power. It should be noted in this respect that rejecting or challenging illocutionary acts does not entail a communicative failure; on the contrary, the awareness of the attempted act is often added to the communicative ground and even can be a clue to interpreting the speaker's behavior. This can be seen in the exchange (21-23) below:

(21) Galya: Why are you defending him? Are you married?

(22) Nadia: What does that have to do with anything?

(23) Galya: So, you are not married. So he did fly to St Petersburg to celebrate New Year's with you.

(The irony of fate or enjoy your bath)

The backfiring strategy involving questions may be interpreted by the speaker (as is illustrated in 23) as a tacit confirmation of what she suspects/ fears/ expects/ anticipates the hearer might answer.

The backfiring strategy can be employed to gain some time in the exchange before having to engage in providing an answer. Consider (24-27):

(24) Това за „Плевен падна" сравненията с...?

Journalist: The "Pleven has fallen" the comparisons with...? 
(25) Това нормално ли е според вас?

Tsvetan Tsvetanov, former Minister of Interior: Do you think that's normal?

(26) АЦ: Според вас нормално ли е? Защо?

Journalist: Do you think that's normal? Why?

(27) ЦЦ: Не разбира се. Защото само да кажа че ако по този начин ние имахме подобно поведение представете си каква емоция и какво трябваше да говорим в нашия предизборен щаб.

T. T.: Of course not. Because let me just say that if we had had a similar behavior can you imagine the emotion and what we would have said in the election camp.

The goal this strategy aims at accomplishing (successfully in this case) is to lead the conversation into subjects that suit the overall strategy of blaming one of the opposition parties of inappropriate behavior after the recent local elections. This is accomplished by interrupting the journalist before she had time to phrase the question to begin with, turning the focus to a moral judgment about inappropriate behavior involving military metaphors considered to be of bad taste. ${ }^{16}$ The journalist did not have a question ready, so she allowed herself to be pulled into a (perhaps) different aspect of the situation. Deflecting whatever kind of question the journalist wanted to ask, the interviewee gains control over the conversation and successfully projects an image of superior moral ground. He did not question overtly the journalist's entitlement to perform the interrupted question, but by suggesting another lead he successfully pulled her into sharing his moral judgment on the inappropriate behavior of the opposing party.

Cases in which an illocutionary act performance is challenged for no procedural reason other than it being at odds with a particular strategic aim of the hearer are typical for strategic interaction situations as those depicted above. It is thus difficult to claim that the speakers choosing and applying strategies can be said to have found breaches in the entitlement condition for the acts they challenged or rejected. Questions that hearers manage to challenge/ reject are the ones they normally anticipate as bound to be asked during the course of the interview. In situation (15)-(16), the participant finds himself confronted with a question he has clearly not anticipated; from the viewpoint of game theory, he has failed in projecting for the desirable outcome in that particular strategic situation. Rejecting or challenging strategies of the participants always serve to project a particular idea about that participant into the social environment and can

16. It refers back to the siege of Pleven, a low point for joint Russian and Bulgarian troops in the Russo-Turkish War of 1877-1878 which ended with Bulgaria gaining independence from the Ottoman Empire. 
be construed as being work on their public image. Sometimes, as in the case of the deputy chairwoman (6), (8) and (10), even though she successfully managed to employ her strategy, the overall benefits from it are very few in terms of her public image, suggesting that success in the application of a challenging or rejecting strategy cannot be a goal in itself. The same observation is valid for (12) and (16). The comparative cost on the image of the participants should be evaluated for both possibilities (accepting or challenging the act of the interlocutor) if they wish to minimize any damage.

As the cases presented above suggest, in strategic interaction a strategy's success will be evaluated in the short term and in the long term. In the short term, the immediate effect of the strategy chosen will consist of whether or not it has fulfilled the short term goal of the speaker. In the case of interview questions, it would amount to successfully challenging or rejecting the unwanted question, limiting appeals to the speaker's responsibility. In the long term, the lingering effect of the strategy would consist in the projected public image of the speaker, which can potentially stretch over future interactions (in politics, this would depend on the attention span of the society).

\section{Conclusions}

Not every string of discourse produced by a speaker constitutes a fully and completely executed illocutionary act. It will be validated or not by the hearer depending on the way the hearer assesses the performance. Within the neo-Austinian framework of illocutionary acts adopted here, it is the entitlement (felicity) condition which serves as a basis for this evaluation. The ultimate goal of using strategies of rejecting and challenging illocutionary acts is to render null or suspend the conventional effect that is necessarily attached to every successful act performance.

In strategic interaction, when speakers and hearers have their own agendas to fulfill and images to build, the interlocutors will attempt to further a particular agenda in order to project an image. Speakers and hearers, who are not merely witnesses to the illocutionary act performance, will exploit their roles resorting to different strategies in constructing their social selves, which can be overtly or covertly confrontational, and which can lead them to challenge or reject illocutionary acts because of clashes with their own strategic goals in a particular situation even if (or especially when) no real breach of procedure can be identified about the illocutionary act performance. The expectations about the appropriateness of acts or their interlocutors' entitlement to perform them are connected to the benefits for the public image the participants wish to project in a particular 
situation; if a discrepancy is perceived, the speakers are likely to seek options which would allow them to gain benefits from the interaction.

Even though in many cases the chosen strategy may lead to a regress (a rejected question will elicit another question, then another, ad infinitum), the format of the exchange will have a profound impact over both the strategy and its short-term success: televised live interviews or live press-conferences usually operate on strict time restrictions, which prevent the interviewer from insisting too much.

Looping can serve as a distraction strategy that can be effective in redirecting the exchange or shifting back the responsibility to the original speaker even without any real procedural breach on the part of the speaker, while backfiring can be employed to demonstrate (real or perceived) infelicities with the act performance. Both strategies are a struggle to assert or project a particular image of the social actor into the social environment; participants' perceptions about each other's images may prove primordial for the success of the strategy: one's reputation of a no-nonsense politician will help in cutting short unfounded questions or accusations. The immediate success of the strategy, however, may have a detrimental effect on the social image of the speaker in the long term. The skills of the interlocutors as strategists will be best evaluated in terms of the long term image work; thus, the best chance of success will lie with social actors who consistently act with accordance to solid integrity, as contrivances are proven to be difficult to manage on the long term.

\section{References}

Akinnaso, Niyi F. 1985. "On the Similarities between Spoken and Written Language." Language and Speech 28(4): 323-359. https://doi.org/10.1177/002383098502800401

Austin, John L. 1962. How to Do Things with Words. Cambridge, Mass.: Harvard U.P.

Bach, Kent, and Harnish, Robert M. 1979. Linguistic Communication and Speech Acts. Cambridge, Mass.: MIT Press.

Caffi, Claudia. 1999. "On Mitigation." Journal of Pragmatics 31: 881-909. https://doi.org/10.1016/S0378-2166(98)00o98-8

Camerer, Colin. 2003. Behavioral Game Theory. Princeton: Princeton University Press.

Clark, Herbert H. and Carlson, Thomas B. 1982. "Hearers and Speech Acts." Language 58(2): 332-373. https://doi.org/10.1353/lan.1982.0042

Dörge, Friedrich C. 2004. Illocutionary Acts: Austin's Account and What Searle Made of It. $\mathrm{PhD}$ dissertation, Tübingen, URL http://deposit.ddb.de/cgi-bin/dokserv?idn=979505232 (Retrieved 01.06.2009).

Goffman, Erving. 1959. The Presentation of Self in Everyday Life. New York: Anchor Books.

Grice, Paul H. 1957. "Meaning." Philosophical Review 66(3): 377-388.

https://doi.org/10.2307/2182440 
Habermas, Jurgen. 2000. On the Pragmatics of Communication. Studies in Contemporary German Social Thought. Cambridge: MIT Press.

Hansson, Sten. 2015. "Calculated Overcommunication: Strategic Uses of Prolixity, Irrelevance, and Repetition in Administrative Language." Journal of Pragmatics 84: 172-188. https://doi.org/10.1016/j.pragma.2015.05.014

Holmes, Janet. 1984. “Modifying Illocutionary Force." Journal of Pragmatics 8(3): 345-365. https://doi.org/10.1016/0378-2166(84)90028-6

Johnson, James. 1991. "Habermas on Strategic and Communicative Action." Political Theory 19(2): 181-201. https://doi.org/10.1177/0090591791019002003

Sbisà, Marina. 1984. “On Illocutionary Types." Journal of Pragmatics 8: 93-112. https://doi.org/10.1016/0378-2166(84)90066-3

Sbisà, Marina. 1992. "Speech Acts, Effects and Responses." In (On) Searle on Conversation, ed. by Herman Parret and Jef Verschueren, 101-112. Amsterdam: John Benjamins. https://doi.org/10.1075/pbns.21.06sbi

Sbisà, Marina. 2001. "Illocutionary Force and Degree of Strength in Language Use." Journal of Pragmatics 33(12): 1791-1814. https://doi.org/10.1016/So378-2166(00)ooo6o-6

Sbisà, Marina. 2002. "Speech Acts in Contexts." Language and Communication 22: 421-436. https://doi.org/10.1016/S0271-5309(02)00018-6

Sbisà, Marina. 2007. "How to Read Austin.” Pragmatics 17(3): 461-473. https://doi.org/10.1075/prag.17.3.06sbi

Sbisà, Marina. 2009. "Uptake and Conventionality in Illocution." Lodz Papers in Pragmatics 5(1): 33-52. https://doi.org/10.2478/v10016-009-0003-0

Sbisa, Marina. 2018. "Varieties of Speech Act Norms". In Normativity and Variety of Speech Actions, ed. by Maciej Witek and Iwona Witczak-Pliciecka. Special issue of Poznan Studies in the Philosophy of the Sciences and the Humanities.

https://doi.org/10.1163/9789004366527_003

Searle, John R. 1969. Speech Acts: An Essay in the Philosophy of Language. Cambridge: Cambridge U.P.. https://doi.org/10.1017/CBO9781139173438

Searle, John R. 1979. Expression and Meaning. Cambridge: Cambridge U.P.. https://doi.org/10.1017/CBO9780511609213

Searle, John R. 1983. Intentionality. Cambridge: Cambridge University Press. https://doi.org/10.1017/CBO9781139173452

Searle, John R. 1992. "Conversation”. In (On) Searle on Conversation, ed. by Herman Parret and Jef Verschueren, 7-30. Amsterdam: John Benjamins. https://doi.org/10.1075/pbns.21.02sea

Streeck, Jürgen. 1992. “The dispreferred other." In (On) Searle on Conversation, ed. by Herman Parret and Jef Verschueren, 129-136. Amsterdam: John Benjamins. https://doi.org/10.1075/pbns.21.08str

Wee, Lionel. 2004. “'Extreme Communicative Acts' and the Boosting Of Illocutionary Force." Journal of Pragmatics 36(12): 2161-2178. https://doi.org/10.1016/j.pragma.2004.01.001

Witek, Maciej. 2015a. "Mechanisms of Illocutionary Games." Language and Communication 42: 11-22. https://doi.org/10.1016/j.langcom.2015.01.007

Witek, Maciej. 2015b. “An Interactional Account Of Illocutionary Practice." Language Sciences 47: 43-55. https://doi.org/10.1016/j.langsci.2014.08.003 


\section{Address for correspondence}

Mariya Chankova

Alliance Francaise

South-West University - Blagoevgrad

66 Ivan Mihaylov str

2700 Blagoevgrad

Bulgaria

mariyachankova@gmail.com

\section{Biographical notes}

Mariya Chankova is Chief Assistant Professor in English and French. Her research interests include linguistic pragmatics, speech act theory, rhetoric, philosophy of language, multimedia environment and communication, plagiarism. She is currently involved in a German-Bulgarian research project on academic plagiarism, funded by the Alexander von Humboldt foundation. 